\title{
The Use of Tomato Powder Fermented with Pediococcus pentosaceus and Lactobacillus sakei for the Ready-to-Cook Minced Meat Quality Improvement
}

\author{
Elena Bartkiene ${ }^{*}$, Grazina Juodeikiene ${ }^{2}$, Daiva Zadeike ${ }^{2}$, Pranas Viskelis ${ }^{3}$ and \\ Dalia Urbonaviciene ${ }^{2,3}$ \\ ${ }^{1}$ Lithuanian University of Health Sciences, Veterinary Academy, Department of Food Safety and Quality, \\ LT-47181 Kaunas, Lithuania \\ ${ }^{2}$ Kaunas University of Technology, Department of Food Science and Technology, LT-50254 Kaunas, Lithuania \\ ${ }^{3}$ Institute of Horticulture, Lithuanian Research Centre for Agriculture and Forestry, LT-54333 Babtai, \\ Kaunas distr., Lithuania \\ Received: December 3, 2013 \\ Accepted: March 16, 2015
}

\begin{abstract}
Summary
In this study, the influence of lactic acid fermentation on the quality of tomato powder was evaluated. The effect of adding fermented tomato powder to ready-to-cook minced pork meat to improve its nutritional value and sensory characteristics was also analysed. The cell growth of Lactobacillus sakei (7.53 log CFU/g) was more intense in the medium containing tomato powder, compared to the growth of Pediococcus pentosaceus ( $6.35 \mathrm{log}$ CFU/g) during $24 \mathrm{~h}$ of fermentation; however, higher acidity $(\mathrm{pH}=4.1)$ was observed in the tomato powder samples fermented with Pediococcus pentosaceus. The spontaneous fermentation of tomato powder reduced cell growth by $38 \%$ and $\mathrm{pH}$ values slightly increased to 4.17 , compared to the fermentation with pure LAB. The lactofermentation of tomato powder increased the average $\beta$-carotene and lycopene mass fractions by 43.9 and $50.2 \%$, respectively, compared with the nonfermented samples. Lycopene and $\beta$-carotene contents in the ready-to-cook minced pork meat were proportional to the added tomato powder (10 and $30 \%)$. After cooking, $\beta$-carotene and lycopene contents decreased, on average, by 24.2 and $41.2 \%$, respectively. The highest loss (up to $49.2 \%$ ) of carotenoids was found in samples with $30 \%$ nonfermented tomato powder. Tomato powder fermented with $10 \%$ Lactobacillus sakei KTU05-6 can be recommended as both a colouring agent and a source of lycopene in the preparation of ready-to-cook minced pork meat.
\end{abstract}

Key words: solid-state fermentation, tomato pulp powder, minced pork meat, carotenoids, colour

\section{Introduction}

There is an increasing demand by consumers for high quality and nutritious meat products. The diverse nutrient composition of meat makes it an ideal environment for the growth and propagation of meat spoilage microorganisms and common foodborne pathogens. Therefore, it is essential that adequate preservation technologies are applied to maintain meat safety and quality (1). The processes used in meat preservation are principally concerned with inhibiting microbial spoilage, although other methods of preservation are sought to minimise deterioration such as colour and oxidative changes (2). The most investigated new preservation technologies for fresh meat 
are nonthermal inactivation technologies such as high hydrostatic pressure (HHP), new packaging systems such as modified atmosphere packaging (MAP) and active packaging (AP), natural antimicrobial compounds and biopreservation. Storage life is extended by using natural or controlled microorganisms, such as lactic acid bacteria (LAB) and their metabolites (e.g. as lactic acid and bacteriocins), which have been studied extensively $(3,4)$. In our previous study, bacteriocin-like inhibitory substances (BLIS) produced by Lactobacillus sakei KTU05-6 and Pediococcus pentosaceus KTU05-9 were designated as sakacin 05-6 and pediocin 05-9, respectively (5). We proposed that these bacteria can be used widely in the food industry as biopreservatives due to their broad inhibition spectrum.

Consumer interest in various fermented foods has increased in recent years due to the positive perception of their impacts on health. Thus, there is a growing need for novel methods of preservation and natural food preservatives. Biopreservation by microorganisms or their metabolites can extend shelf life and enhance safety of foods $(6,7)$.

Lactic acid fermentation represents the easiest and most suitable way to increase daily consumption of 'near$l^{\prime}$ fresh fruits and vegetables. The safety of these products can be aided by the development of starter cultures. There has been progress in the development of antimicrobial LAB strains, which can be engineered to significantly improve the quality, safety and acceptability of plant-based foods. Food matrices, such as vegetables, offer a promising performance as sources and carriers of probiotic strains (8). Vegetables are fundamental sources of water-soluble vitamins (vitamin C and group B vitamins), provitamin A, phytosterols, dietary fibres, minerals and phytochemicals (9) for the human diet. LAB present a small part (2-4 log CFU/g) of the autochthonous microbiota of raw vegetables (10). When favourable conditions of anaerobiosis, water activity, salt concentration and temperature occur, raw vegetables and fruits may be subjected to spontaneous lactic acid fermentation. In some cases, alcoholic fermentation takes place concomitantly (11).

Tomatoes are rich sources of a variety of nutritional compounds and some key antioxidant components such as the carotenoid lycopene, vitamin $\mathrm{C}$, and a range of polyphenols. Consumers have already become aware of the potential importance of the protective properties of these antioxidants. The biochemical composition of tomatoes has been reported extensively in the literature (12). Lycopene, a natural carotenoid, has also been reported to possess various health benefits, such as cardiovascular and cancer-preventive properties (13).

The aim of this study is to evaluate the influence of lactic acid fermentation of tomato pulp powder with bacteriocin-like inhibitory substances (BLIS) produced by Pediococcus pentosaceus KTU05-9 and Lactobacillus sakei KTU05-6 on the quality of fermented tomato products and their effect on the colour, carotenoid content and sensory characteristics of ready-to-cook minced pork meat.

\section{Materials and Methods}

\section{Tomato powder and microorganisms}

Tomato pulp powder was obtained from Obipektin AG (Bischofszell, Switzerland). The lactic acid bacteria
(LAB), Pediococcus pentosaceus KTU05-9 and Lactobacillus sakei KTU05-6, used for the fermentation of tomato powder were obtained from the collection of the Kaunas University of Technology (Kaunas, Lithuania). The LAB were previously isolated from spontaneous rye sourdough (5) and selected due to their inhibition of undesirable bacteria $(14,15)$. The $\mathrm{LAB}$ were stored at $-80^{\circ} \mathrm{C}$ and cultured at $35{ }^{\circ} \mathrm{C}$ (strain KTU05-9) or $30^{\circ} \mathrm{C}$ (strain KTU05-6) for $48 \mathrm{~h}$ in MRS broth (CM0359; Oxoid Ltd, Hampshire, UK) prior to use.

\section{Solid-state fermentation of tomato powder}

Samples were prepared by mixing the tomato powder (300 g) with appropriate amounts of water and LAB culture suspension (10 g), containing an average of 10.1 log of colony-forming units (CFU) per $\mathrm{g}$ (moisture content of $45 \%$, by mass) and incubated at $35{ }^{\circ} \mathrm{C}$ (P. pentosaceus) or $30{ }^{\circ} \mathrm{C}$ (L. sakei) for $48 \mathrm{~h}$. Spontaneous fermentation of tomato powder was carried out at $30^{\circ} \mathrm{C}$ for $48 \mathrm{~h}$ without LAB starters.

\section{Analysis of fermented tomato products}

The $\mathrm{pH}$ value was measured and recorded using a pH electrode (PP-15; Sartorius, Goettingen, Germany). For microbiological analysis, $10 \mathrm{~g}$ of sample were homogenised with $90 \mathrm{~mL}$ of sterile saline $(0.9 \%)$. Serial dilutions $\left(10^{-4}-10^{-8}\right)$ of this suspension were made, spread onto MRS agar and incubated under anaerobic conditions at 30 ${ }^{\circ} \mathrm{C}$ (for L. sakei and spontaneous fermentation) and $35^{\circ} \mathrm{C}$ (for P. pentosaceus) for $72 \mathrm{~h}$. The LAB cell number was calculated and expressed as $\log \mathrm{CFU} / \mathrm{g}$.

\section{Preparation of ready-to-cook minced meat}

Fresh pork loin was obtained from a local market and used for the preparation of the ready-to-cook minced meat. Meat was minced with a meat grinder (hole diameter of $5.0 \mathrm{~mm}$; Meissner AG, Biedenkopf-Wallau, Germany) and mixed with the tomato product (fermented with LAB or spontaneously) at selected mass fractions (10 and $30 \%$ ). Control samples were prepared using minced meat with and without the addition of nonfermented tomato powder. Minced meat samples were covered with plastic film and stored at $4{ }^{\circ} \mathrm{C}$ for $24 \mathrm{~h}$ until analysis. Nontreated and thermally treated (cooked in water at $100{ }^{\circ} \mathrm{C}$ for 10 min) meat samples were subjected to measurements of colour and carotenoid content, and sensory analysis.

\section{Extraction and analysis of carotenoids in ready-to-cook minced meat products}

Prior to analysis, the samples of ready-to-cook minced meat were pureed using a blender (LBC15 Laboratory Blender, Lab Depot Inc., Dawsonville, GA, USA), followed by a few minutes of homogenisation with a Polytron $^{\circledR}$ PT 1200E homogeniser (Kinematica AG, Luzern, Switzerland) at room temperature. A mass of $2 \mathrm{~g}$ of homogenate was extracted with $100 \mathrm{~mL}$ of hexane with the addition of $0.1 \%$ butylated hydroxytoluene (BHT) at room temperature. Extracts were stored at $-20{ }^{\circ} \mathrm{C}$ and equilibrated to room temperature before analysis by HPLC. 
The $\beta$-carotene and lycopene contents were analysed using reversed-phase high performance liquid chromatography (RP-HPLC) (16). A Waters 2695 liquid chromatograph (Waters Corp., Milford, MA, USA) connected to a Waters 2489 UV-VIS detector was used. A $C_{30}$ reversed-phase column $(250 \mathrm{~mm} \times 4.6 \mathrm{~mm}$ i.d.; $3 \mu \mathrm{m})$ from $\mathrm{YMC}$ Corporation (Waters, Zellik, Belgium) was used. The column temperature was $28^{\circ} \mathrm{C}$. The samples were filtered through a $0.45-\mathrm{mm}$ syringe filter (polyvinylidene difluoride, Millipore, Billerica, MA, USA) prior to injection.

The working solutions $(1 \mathrm{mg} / \mathrm{mL})$ of $\beta$-carotene and lycopene standards (Sigma-Aldrich, Taufkirchen, Germany) were prepared daily. The mobile phase consisted of solution A (methanol $100 \%$ ) and solution B (methyl tert-butyl ether $67 \%$ and ethyl acetate $33 \%$ ). The solvent composition for the isocratic elution was as follows: $40 \%$ solvent $\mathrm{A}$ and $60 \%$ solvent $\mathrm{B}$. The elution flow rate was 1.5 $\mathrm{mL} / \mathrm{min}$ and the injection volume was $10 \mathrm{~mL}$. Detection was registered at the wavelength of $473 \mathrm{~nm}$. Carotenoids were identified based on the elution times in comparison with standard reference samples and concurrence with wavelengths for standard compounds.

\section{Sensory evaluation of ready-to-cook minced meat}

Sensory analysis of the ready-to-cook minced meat was performed according to the ISO 8586-1:1993 (17) method by fifteen judges using a 10-score hedonic scale (from $10=$ extremely like, to $0=$ extremely dislike). Coded samples were served and water was provided for rinsing between the sensory evaluations of the samples.

\section{Colour measurements}

The colour characteristics of samples were evaluated at three different positions of the surface using CIELab system (CromaMeter CR-400, Konica Minolta, Kyoto, Japan). $L^{*}$ is a measure of lightness, from completely opaque (0) to completely white (100), $a^{*}$ is a measure of redness (or $-a^{*}$ of greenness), and $b^{*}$ of yellowness (or $-b^{*}$ of blueness). The hue angle $\left(h^{\circ}\right)$ value of the samples indicates the colour tone and was calculated as follows (18):

$$
h^{\circ}=\arctan \left(b^{*} / a^{*}\right)
$$

\section{Statistical analysis}

All analytical determinations were performed at least in triplicate. The obtained data were analysed using statistical package SPSS for Windows XP v. 15.0 (SPSS Inc., Chicago, IL, USA). Significance of differences among the treated samples was evaluated by using Duncan's multiple range tests at a $95 \%$ level of confidence.

\section{Results and Discussion}

\section{Characterisation of fermented tomato pulp powder}

Results of $\mathrm{pH}$ changes and bacterial growth during tomato pulp powder fermentation are presented in Fig. 1. The study showed that tomato powder fermentation time had a significant $(p \leq 0.05)$ influence on bacterial growth rate and changes in $\mathrm{pH}$. Medium with tomato powder in-

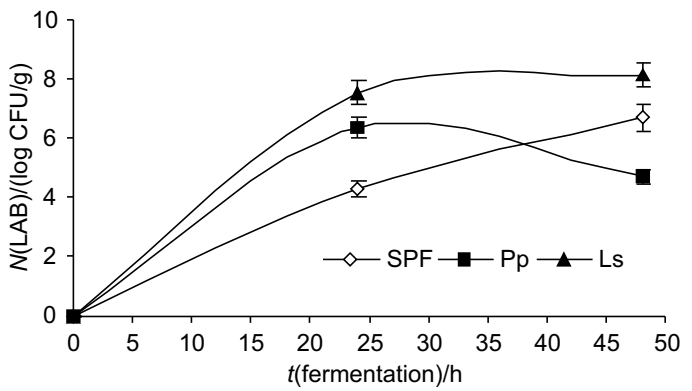

Fig. 1. The viable cell counts of the tested LAB vs. fermentation time in tomato powder fermented with different $\mathrm{LAB}: \mathrm{SPF}=$ spontaneous fermentation, $\mathrm{Pp}=$ Pediococcus pentosaceus, Ls=Lactobacillus sakei

duced the growth of the LAB (Fig. 1). The cell growth of L. sakei strain (7.53 log CFU/g) was more intense than of $P$. pentosaceus (6.35 log CFU/g) during $24 \mathrm{~h}$ of fermentation. Spontaneous fermentation of tomato powder reduced the cell growth by $38 \%$, compared to the fermentation with pure $\mathrm{LAB}$. The tomato powder medium seems to be more suitable for $L$. sakei; the viable cell count of the bacteria reached $8.15 \log \mathrm{CFU} / \mathrm{g}$ after $48 \mathrm{~h}$ of fermentation. A significant $(p \leq 0.05)$ reduction in viable cells was found in the tomato powder samples fermented with $P$. pentosaceus $(26.3 \%)$ after $48 \mathrm{~h}$ of fermentation. In contrast, the spontaneous fermentation of tomato powder showed an increase of bacterial cell counts of $36.2 \%$ during longer fermentation (Fig. 1).

In our previous study (19), L. sakei and P. pentosaceus strains during tomato pulp fermentation reduced the $\mathrm{pH}$ up to 3.5-3.7, and the viable cell counts of the tested strains reached $6.61 \log \mathrm{CFU} / \mathrm{g}$ after $48 \mathrm{~h}$ of tomato pulp fermentation. Spontaneously fermented tomato pulp had $\mathrm{pH}$ values higher by $7.2 \%$ than the lactofermented one.

Both L. sakei and P. pentosaceus were found to be capable of rapid utilisation of tomato pulp powder for cell synthesis and organic acid production. The most intensive formation of organic acids was noticed in the tomato powder samples fermented with $P$. pentosaceus $(\mathrm{pH}=4.1)$. The $\mathrm{pH}$ of the medium was lower (4.1-4.15) than the critical 4.5 value (Fig. 2); in either case, spontaneously fermented tomato products had $\mathrm{pH}$ values slightly higher than the lactofermented products (Fig. 2).

Many authors consider the number of probiotic cells in a food item required to benefit health to be between $10^{6}$

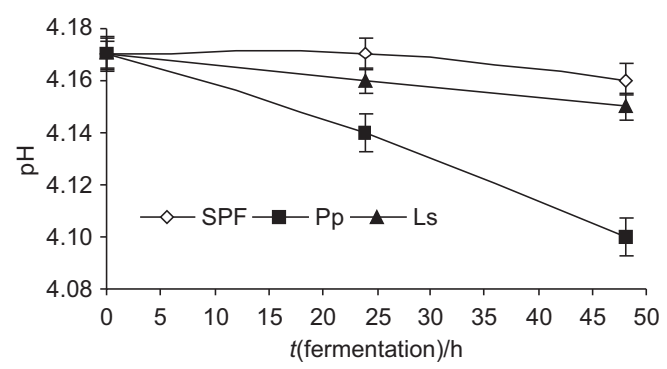

Fig. 2. The $\mathrm{pH}$ values vs. fermentation time in tomato powder fermented with different LAB: SPF=spontaneous fermentation, $\mathrm{P} \mathrm{p}=$ Pediococcus pentosaceus, $\mathrm{Ls}=$ Lactobacillus sakei 
and $10^{8} \mathrm{CFU} / \mathrm{g}(20,21)$. In selecting probiotic bacteria for industrial manufacturing processes, safety, functional and technological characteristics should be considered. Functional properties include the viability of cells, stability of the cells within a food matrix, strain characteristics and fermentation technology $(21,22)$. Our results support the hypothesis that the tomato medium contains the essential nutrients to support the growth of lactobacilli and can be directly used as a fermentation substrate for probiotic lactic acid bacteria. Therefore, the LAB counts were compared to the value of $6.35-8.15 \log \mathrm{CFU} / \mathrm{mL}$, which is considered to be the minimum probiotic count in functional products.

\section{Colour characteristics and carotenoid content of fermented tomato products}

The results of carotenoid analysis of tomato powder samples and their colour values are presented in Fig. 3. According to the results, fermentation significantly ( $\mathrm{p} \leq$ 0.05 ) increased the carotenoid content and influenced the colour characteristics of the tomato powder products (Fig. 3). Total carotenoid mass fractions up to 95.56 and 98.96 mg per $100 \mathrm{~g}$ were measured in tomato samples fermented with $P$. pentosaceus and $L$. sakei, respectively. In addition, spontaneous fermentation increased the content of total carotenoids, but not as effectively; the content of carotenoids in the spontaneously fermented samples was $43.7 \%$ lower compared with the lactofermented samples (Fig. 3).

This study confirmed previous results (19) about the increase of lycopene and total carotenoid contents during lactofermentation of tomatoes. The use of $P$. pentosaceus and L. sakei strains for fermentation of tomato powder increased the mass fractions of total carotenoids on average by 41.1 and $33.6 \%$, respectively, compared to the untreated sample. Lycopene content was found to be lower by $11.0 \%$ in spontaneously fermented tomatoes, compared to the control.

Fermentaton with LAB leads to a disruption of lycopene-protein complexes, breaking down the tomato cell matrix and yielding higher levels of total carotenoids due to increased concentration of cis-lycopene (19). Lycopene content may be affected directly by the $\mathrm{pH}$, as at low $\mathrm{pH}$ tomatoes accumulate more lycopene (23).

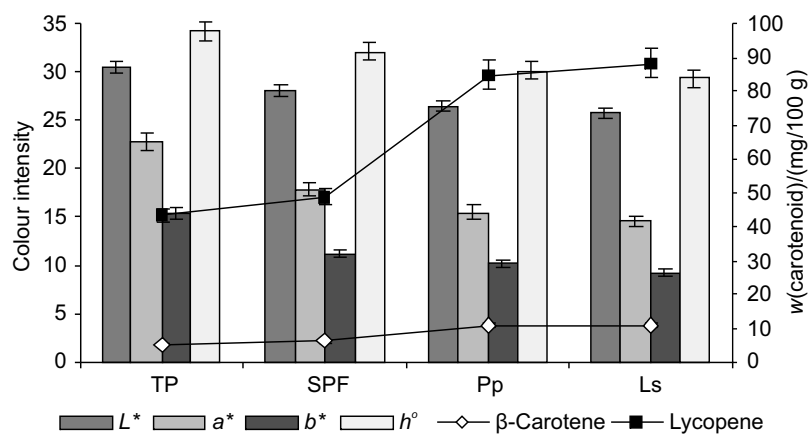

Fig. 3. Colour characteristics and carotenoid content of nontreated (TP) and fermented tomato powder. $\mathrm{SPF}=$ spontaneously fermented, $\mathrm{Pp}=$ fermented with Pediococcus pentosaceus, Ls=fermented with Lactobacillus sakei
Colour is an important quality attribute of the food and bioprocess industries that influences consumer choice and preference. The measurement of food product colour has been used as an indirect evaluation of other quality attributes, such as flavour and contents of pigments, due to the simple and fast measurements and the good correlation with other physicochemical properties (24).

A significant $(\mathrm{p} \leq 0.05)$ decrease in yellowness $\left(b^{*}\right)$ and redness (Fig. 3) with increased contents of $\beta$-carotene and lycopene in the tomato powder after $48 \mathrm{~h}$ of fermentation was detected. In all tomato powder samples, the colour tone $\left(h^{\circ}\right)$ showed mean values ranging from 29.3 to 34.1, indicating an orange colour. Thus, the samples with a lighter colour (higher $L^{*}$ values) tended to be more yellow-orange than the samples with a darker colour (lower $L^{*}$ values). However, the lactofermented samples showed a colour tone $\left(h^{\circ}\right) 7.3$ and $12.9 \%$ lower compared with the spontaneously fermented and tomato powder samples, respectively (Fig. 3). A strong negative linear correlation was observed between $\beta$-carotene and lycopene contents and lightness $\left(L^{*}\right)\left(R^{2}=0.835\right.$ and $R^{2}=0.846$, respectively), and also between the colour tone $\left(h^{\circ}\right)$ and lycopene content $\left(\mathrm{R}^{2}=0.904, \mathrm{p} \leq 0.001\right)$. A strong positive linear relationship was observed between $L^{*}$ and $h^{\circ}\left(\mathrm{R}^{2}=0.830, \mathrm{p} \leq 0.001\right)$. The colour change of a tomato product is an indication of the fermentation procedure and is related to its pigment concentration.

Our previous study showed a weak correlation between the yellow colour $\left(b^{*}\right)$ values and $\beta$-carotene content and a strong correlation between $b^{*}$ and lycopene content in tomato samples (19). As was reported by Fernández-Ruiz et al. (25), the measurement of the yellow coordinate $\left(b^{*}\right)$ could be used for predicting lycopene content in tomato products.

\section{The influence of fermented tomato powder on sensory characteristics of ready-to-cook minced meat}

Significant differences were found in the intensity of acidity, colour and acceptability of ready-to-cook minced meat with different amounts of tomato powder fermented with pure LAB or spontaneously fermented (Fig. 4). The intensity scores for acid taste of ready-to-cook minced

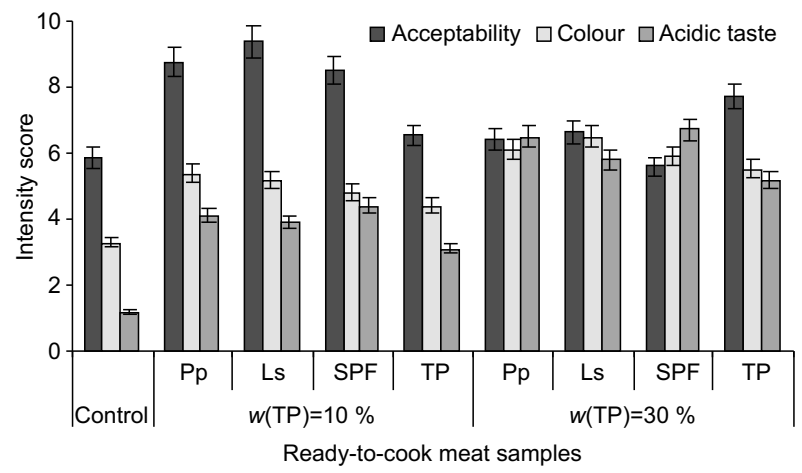

Fig. 4. Intensity of colour, taste and acceptability of ready-to-cook minced meat prepared without and with tomato powder addition. Control=without tomato powder, $\mathrm{TP}=$ with tomato powder, $\mathrm{SPF}=$ spontaneously fermented, $\mathrm{Pp}=$ fermented with Pediococcus pentosaceus, Ls=fermented with Lactobacillus sakei 
meat with $10 \%$ tomato powder varied between 3.1 and 4.4. The lowest score was of the ready-to-cook minced meat samples with $10 \%$ nonfermented tomato powder. The ready-to-cook minced meat samples with $30 \%$ tomato powder had the most intensive colour (5.5-6.5) and acidity (5.2-6.7) (Fig. 4).

The ready-to-cook minced meat with $10 \%$ tomato powder fermented with $L$. sakei and P. pentosaceus had the highest acceptability scores (9.4 and 8.8, respectively) (Fig. 4 ). Acceptability scores of the control sample (without additives) were found to be lower by 34.2 and $5.6 \%$, respectively, than those with fermented tomato powder. The ready-to-cook minced meat samples with $30 \%$ fermented tomato powder had a lower acceptability (by $30.3 \%$ ) than those with $10 \%$ fermented tomato powder, due to an undesirable acidic taste. However, the ready-to-cook minced meat samples with $30 \%$ nonfermented tomato powder were rated as highly acceptable (an average of 7.7) (Fig. 4).

\section{The influence of tomato additives on colour and carotenoid content of ready-to-cook minced meat}

Considering the colour properties of tomato products and the beneficial effects on human health (26-28), their addition to meat products could reduce the necessity of adding synthetic colourants and yield products with a better nutritional profile due to the higher content of plant-derived bioactive compounds (lycopene and phenolic compounds) (29). The Joint FAO/WHO Expert Committee on Food Additives (JECFA) agreed that lycopene (both natural and synthetic) is acceptable as a food colourant and established a group acceptable daily intake (ADI) of $0-0.5 \mathrm{mg}$ of both preparations per $\mathrm{kg}$ of body mass per day (30). According to Descalzo et al. (31), mass fractions of $\beta$-carotene in fresh meat could range between 5 and $50 \mu \mathrm{g}$ per $100 \mathrm{~g}$ depending on food intake. Few studies have reported the use of tomato products or lycopene in meat products. Candogan (32) and Deda et al. (33) reported on the impact of the addition of tomato paste or tomato peel on the quality and sensorial properties of beef patties and frankfurters. Calvo et al. (34) used tomato peel for the enrichment of dry fermented sausages with lycopene. However, data on the effect of fermented tomato products on ready-to-cook minced meat quality parameters have not been found.

Our study showed that the addition of fermented tomato powder significantly affected $(p \leq 0.05)$ the colour characteristics of the ready-to-cook minced meat (Table $1)$. The controls (without tomato powder) had significantly higher $(\mathrm{p} \leq 0.05)$ values of lightness $\left(L^{*}\right)$ and the lowest $(\mathrm{p} \leq 0.05)$ values of redness $\left(a^{*}\right)$ and yellowness $\left(b^{*}\right)$. The addition of 10 and $30 \%$ of fermented tomato powder in-

Table 1. Effect of the addition of tomato powder on the colour characteristics of nontreated and thermally treated (10 min in water at $100{ }^{\circ} \mathrm{C}$ ) ready-to-cook minced meat

\begin{tabular}{|c|c|c|c|c|c|}
\hline \multicolumn{2}{|c|}{ Samples } & $L^{*}$ & $a^{*}$ & $b^{*}$ & $h^{\circ}$ \\
\hline \multicolumn{6}{|c|}{ Nontreated } \\
\hline Control & & $(58.38 \pm 0.48)^{\mathrm{e}}$ & $(3.93 \pm 0.18)^{\mathrm{a}}$ & $(15.33 \pm 0.78)^{\mathrm{a}}$ & $(81.18 \pm 0.54)^{\mathrm{e}}$ \\
\hline \multicolumn{6}{|c|}{$w(\mathrm{TP}) / \%$} \\
\hline \multirow{4}{*}{10} & $\mathrm{Pp}$ & $(50.64 \pm 0.19)^{\mathrm{d}}$ & $(12.90 \pm 0.72)^{c}$ & $(26.90 \pm 0.74)^{d}$ & $(65.99 \pm 0.93)^{\mathrm{d}}$ \\
\hline & Ls & $(50.90 \pm 0.79)^{\mathrm{d}}$ & $(12.14 \pm 0.21)^{c}$ & $(27.60 \pm 0.52)^{\mathrm{de}}$ & $(66.93 \pm 0.88)^{\mathrm{d}}$ \\
\hline & SPF & $(45.21 \pm 0.41)^{\mathrm{a}}$ & $(14.02 \pm 0.19)^{\mathrm{d}}$ & $(21.45 \pm 0.41)^{c}$ & $(61.33 \pm 0.46)^{\mathrm{b}}$ \\
\hline & $\mathrm{TP}$ & $(44.25 \pm 0.39)^{\mathrm{a}}$ & $(11.03 \pm 0.11)^{\mathrm{b}}$ & $(19.56 \pm 0.59)^{b}$ & $(60.84 \pm 0.93)^{\mathrm{b}}$ \\
\hline \multirow{4}{*}{30} & $\mathrm{Pp}$ & $(46.03 \pm 0.25)^{\mathrm{a}}$ & $(17.27 \pm 0.51)^{\mathrm{e}}$ & $(28.96 \pm 0.83)^{\mathrm{f}}$ & $(57.30 \pm 0.40)^{a}$ \\
\hline & Ls & $(45.63 \pm 0.63)^{\mathrm{a}}$ & $(18.08 \pm 0.61)^{\mathrm{e}}$ & $(28.50 \pm 0.48)^{\mathrm{f}}$ & $(56.77 \pm 0.68)^{\mathrm{a}}$ \\
\hline & SPF & $(47.23 \pm 0.28)^{\mathrm{b}}$ & $(15.23 \pm 0.34)^{\mathrm{d}}$ & $(25.36 \pm 0.39)^{\mathrm{d}}$ & $(62.39 \pm 0.45)^{\mathrm{c}}$ \\
\hline & $\mathrm{TP}$ & $(46.27 \pm 0.52)^{\mathrm{b}}$ & $(13.25 \pm 0.16)^{\mathrm{c}}$ & $(21.55 \pm 0.57)^{c}$ & $(61.45 \pm 0.41)^{\mathrm{b}}$ \\
\hline \multicolumn{6}{|c|}{ Thermally treated } \\
\hline Control & & $(60.07 \pm 0.43)^{\mathrm{e}}$ & $(2.41 \pm 0.30)^{a}$ & $(11.84 \pm 0.22)^{\mathrm{a}}$ & $(82.71 \pm 0.60)^{\mathrm{f}}$ \\
\hline \multicolumn{6}{|c|}{$w(\mathrm{TP}) / \%$} \\
\hline \multirow{4}{*}{10} & $\mathrm{Pp}$ & $(43.51 \pm 0.11)^{\mathrm{a}}$ & $(8.21 \pm 0.32)^{c}$ & $(17.75 \pm 0.39)^{c}$ & $(52.75 \pm 0.97)^{\mathrm{a}}$ \\
\hline & Ls & $(52.76 \pm 0.18)^{\mathrm{d}}$ & $(10.80 \pm 0.81)^{\mathrm{e}}$ & $(23.05 \pm 0.52)^{\mathrm{e}}$ & $(63.83 \pm 0.78)^{\mathrm{d}}$ \\
\hline & SPF & $(48.45 \pm 0.19)^{c}$ & $(9.31 \pm 0.74)^{\mathrm{cd}}$ & $(21.89 \pm 0.64)^{\mathrm{d}}$ & $(66.96 \pm 0.88)^{\mathrm{e}}$ \\
\hline & $\mathrm{TP}$ & $(42.14 \pm 0.17)^{a}$ & $(4.32 \pm 0.37)^{\mathrm{b}}$ & $(12.32 \pm 0.60)^{a}$ & $(52.65 \pm 0.55)^{a}$ \\
\hline \multirow{4}{*}{30} & $\mathrm{Pp}$ & $(45.64 \pm 0.11)^{\mathrm{a}}$ & $(19.09 \pm 0.21)^{f}$ & $(28.16 \pm 0.69)^{\mathrm{f}}$ & $(55.87 \pm 0.96)^{\mathrm{b}}$ \\
\hline & Ls & $(47.96 \pm 0.20)^{\mathrm{c}}$ & $(19.27 \pm 0.93)^{\mathrm{f}}$ & $(29.93 \pm 0.71)^{\mathrm{g}}$ & $(57.22 \pm 0.63)^{\mathrm{c}}$ \\
\hline & SPF & $(44.54 \pm 0.23)^{\mathrm{b}}$ & $(12.01 \pm 0.63)^{\mathrm{e}}$ & $(20.33 \pm 0.55)^{\mathrm{d}}$ & $(54.32 \pm 0.49)^{a}$ \\
\hline & $\mathrm{TP}$ & $(42.10 \pm 0.25)^{\mathrm{a}}$ & $(7.56 \pm 0.41)^{c}$ & $(14.24 \pm 0.44)^{\mathrm{b}}$ & $(53.66 \pm 0.86)^{a}$ \\
\hline
\end{tabular}

Mean values in a column with different letters are significantly different $(\mathrm{p} \leq 0.05)$.

Control=without additives, $\mathrm{TP}=$ tomato powder, $\mathrm{SPF}=$ spontaneously fermented tomato powder, $\mathrm{Pp}=$ tomato powder fermented with $P$. pentosaceus, Ls=tomato powder fermented with L. sakei 
creased the redness by 70.2 and $77.8 \%$ and yellowness by 1.8 and 1.9-fold, respectively, of the ready-to-cook minced meat, which were more attractive to consumers than the control samples. Spontaneous fermentation improved the yellowness of ready-to-cook minced meat at a lower level $(28.5 \%)$ (Table 1). These tendencies were detected for both nontreated and thermally treated ready-to-cook minced meat samples.

Large variation in the colour parameters of meat products due to the different measurement conditions, the composition of the meat products and the size of the meat particles has been reported $(35,36)$. According to our results, the meat colour parameters were significantly affected by the amount of the added tomato powder and the treatment of ready-to-cook minced meat. In general, the addition of lycopene to meat products, through the addition of tomato pasta or peel, led to changes in the typical red colour of the meat products by increasing the yellow colour and providing an orange tone $(37,38)$.

The results of the carotenoid analysis of the ready-to-cook minced meat are presented in Table 2. The lycopene and $\beta$-carotene contents of the ready-to-cook minced meat increased from 0.48 to $10.32 \mathrm{mg}$ per $100 \mathrm{~g}$ and from 0.19 to $1.95 \mathrm{mg}$ per $100 \mathrm{~g}$, respectively, depending on the percentage of tomato powder in the formulation (10 or 30

Table 2. Effect of the addition of tomato powder on carotenoid content in nontreated and thermally treated (10 min in water at $100{ }^{\circ} \mathrm{C}$ ) ready-to-cook minced meat

\begin{tabular}{|c|c|c|c|c|}
\hline \multirow{2}{*}{\multicolumn{2}{|c|}{ Samples }} & \multicolumn{3}{|c|}{$w /(\mathrm{mg} / 100 \mathrm{~g})$} \\
\hline & & \multirow{2}{*}{\multicolumn{2}{|c|}{$\frac{\beta \text {-Carotene } \quad \text { Lycopene }}{\text { Nontreated }}$}} & \multirow[t]{2}{*}{$\begin{array}{c}\text { Total } \\
\text { carotenoids }\end{array}$} \\
\hline & & & & \\
\hline \multicolumn{5}{|c|}{$w(\mathrm{TP}) / \%$} \\
\hline \multirow{4}{*}{10} & $\mathrm{Pp}$ & $(1.01 \pm 0.07)^{\mathrm{d}}$ & $(3.67 \pm 0.21)^{\mathrm{d}}$ & $(4.68 \pm 0.13)^{d}$ \\
\hline & Ls & $(1.23 \pm 0.09)^{\mathrm{d}}$ & $(3.59 \pm 0.21)^{\mathrm{d}}$ & $(4.82 \pm 0.11)^{\mathrm{c}}$ \\
\hline & SPF & $(0.69 \pm 0.02)^{c}$ & $(1.02 \pm 0.09)^{\mathrm{b}}$ & $(1.71 \pm 0.06)^{\mathrm{b}}$ \\
\hline & $\mathrm{TP}$ & $(0.19 \pm 0.02)^{a}$ & $(0.48 \pm 0.06)^{a}$ & $(0.67 \pm 0.05)^{\mathrm{a}}$ \\
\hline \multirow{4}{*}{30} & $\mathrm{Pp}$ & $(1.76 \pm 0.03)^{\mathrm{e}}$ & $(10.32 \pm 0.11)^{\mathrm{e}}$ & $(12.08 \pm 0.07)^{\mathrm{e}}$ \\
\hline & Ls & $(1.95 \pm 0.08)^{\mathrm{e}}$ & $(9.66 \pm 0.17)^{e}$ & $(11.61 \pm 0.14)^{\mathrm{e}}$ \\
\hline & SPF & $(0.97 \pm 0.02)^{c}$ & $(2.13 \pm 0.15)^{c}$ & $(3.1 \pm 0.09)^{c}$ \\
\hline & $\mathrm{TP}$ & $(0.25 \pm 0.01)^{\mathrm{b}}$ & $(1.46 \pm 0.10)^{\mathrm{b}}$ & $(1.71 \pm 0.06)^{\mathrm{b}}$ \\
\hline \multicolumn{5}{|c|}{ Thermally treated } \\
\hline \multicolumn{5}{|c|}{$w(\mathrm{TP}) / \%$} \\
\hline \multirow{4}{*}{10} & $\mathrm{Pp}$ & $(0.76 \pm 0.06)^{c}$ & $(2.62 \pm 0.20)^{c}$ & $(3.38 \pm 0.14)^{c}$ \\
\hline & Ls & $(0.59 \pm 0.06)^{\mathrm{b}}$ & $(2.15 \pm 0.13)^{c}$ & $(2.74 \pm 0.20)^{\mathrm{c}}$ \\
\hline & SPF & $(0.49 \pm 0.07)^{\mathrm{b}}$ & $(0.91 \pm 0.06)^{\mathrm{b}}$ & $(1.40 \pm 0.05)^{\mathrm{b}}$ \\
\hline & $\mathrm{TP}$ & $(0.10 \pm 0.02)^{\mathrm{a}}$ & $(0.24 \pm 0.07)^{\mathrm{a}}$ & $(0.34 \pm 0.03)^{\mathrm{a}}$ \\
\hline \multirow{4}{*}{30} & $\mathrm{Pp}$ & $(1.17 \pm 0.10)^{\mathrm{d}}$ & $(6.31 \pm 0.26)^{\mathrm{d}}$ & $(7.48 \pm 0.17)^{\mathrm{d}}$ \\
\hline & Ls & $(1.47 \pm 0.08)^{\mathrm{d}}$ & $(7.32 \pm 0.14)^{\mathrm{d}}$ & $(8.79 \pm 0.09)^{\mathrm{d}}$ \\
\hline & SPF & $(0.74 \pm 0.04)^{c}$ & $(1.75 \pm 0.09)^{c}$ & $(2.49 \pm 0.07)^{\mathrm{c}}$ \\
\hline & $\mathrm{TP}$ & $(0.15 \pm 0.04)^{\mathrm{a}}$ & $(0.93 \pm 0.05)^{\mathrm{b}}$ & $(1.08 \pm 0.05)^{\mathrm{b}}$ \\
\hline
\end{tabular}

Mean values in a column with different letters are significantly different $(\mathrm{p} \leq 0.05)$. $\mathrm{TP}=$ tomato powder, $\mathrm{SPF}=$ spontaneously fermented tomato powder, $\mathrm{Pp}=$ tomato powder fermented with $P$. pentosaceus, Ls=tomato powder fermented with $\mathrm{L}$. sakei
$\%$ ) (Table 2). The addition of lactofermented tomato powder provided $\beta$-carotene and lycopene contents of on average 1.12 and $3.63 \mathrm{mg}$ per $100 \mathrm{~g}$ (10\% of tomato powder), respectively, and 1.86 and $9.99 \mathrm{mg}$ per $100 \mathrm{~g}$ (30\% of tomato powder), respectively. The ready-to-cook minced meat with spontaneously fermented tomato powder had $\beta$-carotene and lycopene contents that were 43 and $75 \%$ lower, respectively, compared to the ready-to-cook minced meat with lactofermented tomato powder. The lowest mass fractions of $\beta$-carotene and lycopene measured in the ready-to-cook minced meat samples were 0.9 and 0.48 mg per $100 \mathrm{~g}$ with $10 \%$ and 0.25 and $1.46 \mathrm{mg}$ per $100 \mathrm{~g}$ with $30 \%$ of nonfermented tomato powder, respectively.

The content of lycopene in ready-to-cook minced meat with lactofermented tomato powder was higher than that reported by Doménech-Asensi et al. (37) in mortadella after the addition of tomato paste. The lycopene in our ready-to-cook minced meat samples is expected to be more available, since it originates from tomato powder in which both heat treatment and fermentaton with LAB lead to higher levels of total carotenoids due to an increased concentration of cis-lycopene (19).

Cooking the ready-to-cook minced meat in water lowered the $\beta$-carotene and lycopene contents as well as the total carotenoid content (Fig. 5). Mean carotenoid losses of up to $22-28 \%$ and up to $30-41 \%$ were detected in ready-to-cook minced meat samples with 10 and $30 \%$ fermented tomato powder, respectively. As a consequence, the highest loss of total carotenoids was found in samples with 10 and $30 \%$ of nonfermented tomato powder (38 and $49 \%$, respectively) (Table 2 ).

Heat and different food matrices are factors that have an effect on lycopene isomerisation and autoxidation. Lycopene may isomerise to mono- or poly-cis forms in the presence of heat or fat, or during dehydration. Heat treatment of oil-rich meat products supplemented with tomatoes could increase lycopene losses due to the heat treatment in the fat-water emulsion $(38,39)$.

The addition of fermented tomato powder did not affect negatively technological processing, so the minced meat with $10 \%$ fermented tomato powder was a suitable product with the added benefit of the presence of lycopene and a positive effect on overall consumer acceptance.

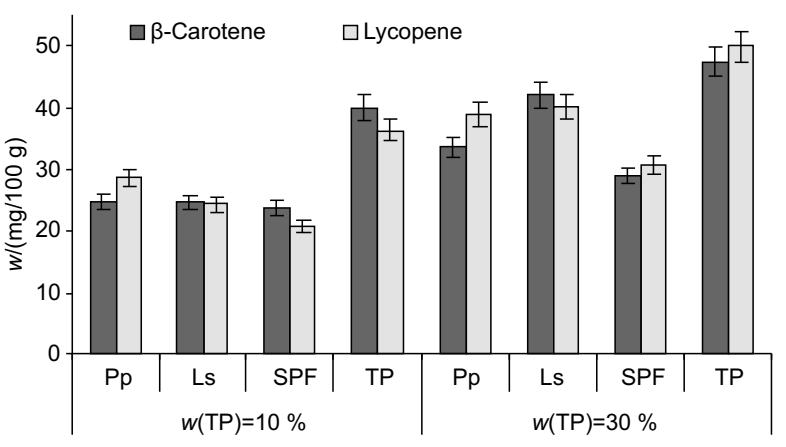

Ready-to-cook meat samples

Fig. 5. Reduction in lycopene and $\beta$-carotene contents during thermal treatment $\left(10 \mathrm{~min}\right.$ in water at $\left.100{ }^{\circ} \mathrm{C}\right)$ of ready-to-cook minced meat. $\mathrm{TP}=$ tomato powder, $\mathrm{SPF}=$ spontaneously fermented tomato powder, $\mathrm{Pp}=$ tomato powder fermented with $P$. pentosaceus, Ls=tomato powder fermented with L. sakei 


\section{Conclusions}

The direct use of Pediococcus pentosaceus KTU05-9 and Lactobacillus sakei KTU05-6 in fermentation of tomato powder increases its carotenoid content, and makes it a beneficial additive that improves the colour and nutritional value of minced meat. $L$. sakei showed a $43.8 \%$ more intensive cell growth during the solid-state fermentation of tomato powder compared to $P$. pentosaceus. Moreover, according to our previous research (19), the $P$. pentosaceus strain produces mainly D-lactic acid (L/D ratio of 0.64 ), while L. sakei produces mainly L-lactic acid (L/D ratio of 1.61) during the fermentation of tomatoes. Because of the potential toxicity of D-lactic acid in food, the tomato products prepared using selected LAB cultures are safer than those that are spontaneously fermented.

The addition of tomato products to minced pork meat allowed to change the typical colour of the meat products by increasing the yellow colour and providing an orange tone. The Lactobacillus sakei KTU05-6 could be recommended for the fermentation of tomato powder to improve the nutritional value and colour of the minced meat without effects on overall consumer acceptance. This is the first report of tomato powder fermented with selected lactobacilli used as a source of lycopene and $\beta$ -carotene for meat products, and more research is needed to explain the mechanism of carotenoid increase during fermentation.

\section{Acknowledgement}

The authors gratefully acknowledge the Research Council of Lithuania for the financial support (Project no. SVE-02/2011).

\section{References}

1. Aymerich T, Picouet PA, Monfort JM. Decontamination technologies for meat products. Meat Sci. 2008;78:114-29. http://dx.doi.org/10.1016/j.meatsci.2007.07.007

2. Zhou GH, Xu XL, Liu Y. Preservation technologies for fresh meat - a review. Meat Sci. 2010;86:119-28. http://dx.doi.org/10.1016/j.meatsci.2010.04.033

3. Stiles ME, Hastings JW. Bacteriocin production by lactic acid bacteria: potential for use in meat preservation, Trends Food Sci Technol. 1991;2:247-51. http://dx.doi.org/10.1016/0924-2244(91)90706-O

4. Klaenhammer TR, Genetics of bacteriocins produced by lactic acid bacteria. FEMS Microbiol Rev. 1993;12:39-86. http://dx.doi.org/10.1111/j.1574-6976.1993.tb00012.x

5. Digaitiene A, Hansen A, Juodeikiene G, Josephsen J. Microbial population in Lithuanian spontaneus rye sourdougs. Ekologia i Technika. 2005;13:193-8.

6. Ross RP, Morgan S, Hill C. Preservation and fermentation: past, present and future. Int J Food Microbiol. 2002;79:3-16. http://dx.doi.org/S0168-1605(02)00174-5

7. El-Ghaish S, Ahmadova A, Hadji-Sfaxi I, El Mecherfi KE, Bazukyan I, Choiset $Y$, et al. Potential use of lactic acid bacteria for reduction of allergenicity and for longer conservation of fermented foods. Trends Food Sci Technol. 2011;22:509-16. http://dx.doi.org/10.1016/j.tifs.2011.05.003

8. Peres CM, Peres C, Hernandez-Mendoza A, Malcata FX. Review on fermented plant materials as carriers and sources of potentially probiotic lactic acid bacteria - with an emphasis on table olives. Trends Food Sci Technol. 2012; 26:31-42. http://dx.doi.org/10.1016/j.tifs.2012.01.006

9. Gebbers JO. Atherosclerosis, cholesterol, nutrition, and statins - a critical review. GMS Ger Med Sci. 2007;5:1-11. http://dx.doi.org/10.3205/000181

10. Buckenhüskes HJ. Fermented vegetables. In: Doyle PD, Beuchat LR, Montville TJ, editors. Food microbiology: fundamentals and frontiers. Washington, DC, USA: ASM Press; 1997. pp. 595-609.

11. Di Cagno R, Coda R, De Angelis M, Gobbetti M. Exploitation of vegetables and fruits through lactic acid fermentation. Food Microbiol. 2013;33:1-10. http://dx.doi.org/10.1016/j.fm.2012.09.003

12. Capanoglu E, Beekwilder J, Boyacioglu D, De Vos RCH, Hall $\mathrm{RD}$. The effect of industrial food processing on potentially health beneficial tomato antioxidants. Crit Rev Food Sci Nutr. 2010;50:919-31. http://dx.doi.org/10.1080/10408390903001503

13. Palozza P, Parrone N, Simone RE, Catalano A. Tomato lycopene and inflammatory cascade: basic interactions and clinical implications. Curr Med Chem. 2010;17:2547-63.

14. Narbutaite V, Fernandez A, Horn N, Juodeikiene G, Narbad A. Influence of baking enzymes on antimicrobial activity of five bacteriocin-like inhibitory substances produced by lactic acid bacteria isolated from Lithuanian sourdoughs. Lett Appl Microbiol. 2008;47:555-60.

http://dx.doi.org/10.1111/j.1472-765X.2008.02466.x

15. Digaitiene A, Hansen AS, Juodeikiene G, Eidukonyte D, Josephsen J. Lactic acid bacteria isolated from rye sourdoughs produce bacteriocin-like inhibitory substances active against Bacillus subtilis and fungi. J Appl Microbiol. 2012;112:732-42. http://dx.doi.org/10.1111/j.1365-2672.2012.05249.x

16. Urbonaviciene D, Viskelis P, Viskelis J, Jankauskiene J, Bobinas $C$. Lycopene and $\beta$-carotene in non-blanched and blanched tomatoes. J Food Agric Environ. 2012;10:142-6.

17. ISO 8586-1:1993. Sensory analysis - General guidance for the selection, training and monitoring of assessors - Part 1: Selected assessors. Geneva, Switzerland: International Organization for Standardization; 1993.

18. Mc Guire RG. Reporting of objective color measurements. Hortic Sci. 1992;27:1254-5.

19. Bartkiene E, Juodeikiene G, Vidmantiene D, Viskelis P, Urbonaviciene D. Lactic acid fermentation of tomato: effects on cis/trans lycopene isomer ratio, $\beta$-carotene mass fraction and formation of $\mathrm{L}(+)$ and $\mathrm{D}(-)$-lactic acid. Food Technol Biotechnol. 2013;51:471-8.

20. Lourens A, Viljoen BC, Jooste P. Levels of probiotic bacteria in South African commercial bio-yogurt. S Afr Food Rev. 2000;27:31-3.

21. Georgieva R, Koleva P, Nikolova D, Yankov D, Danova S. Growth parameters of probiotic strain Lactobacillus plantarum, isolated from traditional white cheese. Biotechnol Biotechnol Equip. 2009;23:861-5. http://dx.doi.org/10.1080/13102818.2009.10818558

22. Rathore S, Salmeron I, Pandiella SS. Production of potentially probiotic beverages using single and mixed cereal substrates fermented with lactic acid bacteria cultures. Food Microbiol. 2012;30:239-44. http://dx.doi.org/10.1016/j.fm.2011.09.001

23. Gould WA. Quality evaluation of processed tomato juice. J Agric Food Chem. 1978; 26:1006-11.

24. Pathare PB, Opara UL, Al-Julanda Al-Said F. Colour measurement and analysis in fresh and processed foods: a review. Food Bioprocess Tech. 2013;6:36-60. http://dx.doi.org/10.1007/s11947-012-0867-9

25. Fernández-Ruiz V, Torrecilla JS, Cámara M, Mata MC, Shoemaker C. Radial basis network analysis of color parameters 
to estimate lycopene content on tomato fruits. Talanta. 2010; 83:9-13. http://dx.doi.org/10.1016/j.talanta.2010.08.020

26. Kavanaugh CJ, Trumbo PR, Ellwood KC. The US food and drug administration's evidence-based review for qualified health claims: tomatoes, lycopene and cancer. J Natl Cancer Inst. 2007;99:1074-85. http://dx.doi.org/10.1093/jnci/djm037

27. Khachik F, Carvalho L, Bernstein PS, Muir GJ, Zhao DY, Katz NB. Chemistry, distribution and metabolism of tomato carotenoids and their impact in human health. Exp Biol Med. 2002;227:845-51.

28. Rao AV, Rao LG. Lycopene and human health. Curr Top Nutr Res. 2004;2:127-37.

29. WHO Technical Report No. 557. Evaluation of certain food additives: 18th report of the Joint FAO/WHO Expert Committee on Food Additives. Geneva, Swizerland: FAO/WHO World Health Organization; 1975. http://www.who.int/iris/handle/10665/41117

30. WHO Technical Report No. 940. Evaluation of certain food additives: 67th report of the Joint FAO/WHO Expert Committee on Food Additives. Geneva, Swizerland: FAO/WHO World Health Organization; 2006. http://www.who.int/WHO_TRS_940.pdf

31. Descalzo A, Insani EM, Biolatto A, Sancho AM, Garcia PT, Pensel NA. Influence of pasture or grain-based diets supplemented with vitamin $\mathrm{E}$ on antioxidant/oxidative balance of Argentine beef. Meat Sci. 2005;70:35-44. http://dx.doi.org/10.1016/j.meatsci.2004.11.018

32. Candogan $\mathrm{K}$. The effect of tomato paste on some quality characteristics of beef patties during refrigerated storage. Eur Food
Res Technol. 2002;215:305-9. http://dx.doi.org/10.1007/s00217-002-0567-1

33. Deda MS, Bloukas JG, Fista GA. Effect of tomato paste and nitrite level on processing and quality characteristics of frankfurters. Meat Sci. 2007;76:501-8. http://dx.doi.org/10.1016/j.meatsci.2007.01.004

34. Calvo MM, Garcia ML, Selgas MDM. Dry fermented sausages enriched with lycopene from tomato peel. Meat Sci. 2008; 80:167-72.

http://dx.doi.org/10.1016/j.meatsci.2007.11.016

35. Gimeno O, Astiasaran I, Bello J. Calcium ascorbate as a potential partial substitute for $\mathrm{NaCl}$ in dry fermented sausage: Effect on colour, texture and hygienic quality at different concentration. Meat Sci. 2001;57:23-9.

http://dx.doi.org/10.1016/S0309-1740(00) 00113-3

36. Jakobsen M, Bertelsen G. Modelling colour stability. In: MacDougall D, editor. Colour in food: improving quality. London, UK: Woodhead Publishing Ltd.; 2002. pp. 233-47.

37. Doménech-Asensi G, García-Alonso FJ, Martínez E, Santaella M, Martín-Pozuelo G, Bravo S, Periago MJ. Effect of the addition of tomato paste on the nutritional and sensory properties of mortadella. Meat Sci. 2013;93:213-9. http://dx.doi.org/10.1016/j.meatsci.2012.08.021

38. Sharma SK, Maguer ML. Kinetics of lycopene degradation in tomato pulp solids during under different processing and storage conditions. Food Res Int. 1996;29:309-15. http://dx.doi.org/10.1016/0963-9969(96)00029-4

39. Ax K, Mayer-Miebach E, Link B, Schuchmann H, Schubert H. Stability of lycopene in oil-in-water emulsions. Eng Life Sci. 2003;4:199-201. http://dx.doi.org/10.1002/elsc.200390028 